\title{
SYNERGISTIC AND COMPLEMENTARY SAFETY SUPERVISION MODE IN COAL MINES: A CASE OF COAL MINING COMPANIES IN CHINA
}

\author{
Lifen Fang, Zaixu Zhang, Xingdong Li
}

Original scientific paper Effective safety supervision guarantees coal mine safety production. However, the traditional supervision mode in Chinese coal mines cannot fully realize the synergistic and complementary effects of elements (i.e., safety inspectors) of safety supervision system, which causes information-isolated island, application-isolated island, and resource-isolated island. To overcome these deficiencies and improve the efficiency of safety supervision, a synergistic and complementary safety supervision mode (SCSSM) was explored in this study. After the applicability analysis of the synergistic and complementary management idea, this study creatively introduced the proposed idea to the safety supervision in the coal mine. On the basis of the deficiencies of the existing safety supervision mode and the advantages of synergistic and complementary management, the SCSSM was then established and its definite operation method was also provided. Finally, the new safety supervision mode was applied in Xinwen Mining Group Xin Julong Co., Ltd. with definite implementation method and comparative analysis. Results show that the new safety supervision mode uses lesser safety supervision resources than the traditional one. Meanwhile, the checking and rectification efficiency of hidden dangers and the project qualified rate are improved. Moreover, the number of accidents is reduced, which has significant safety, economic, and social benefits. This study can realize the synergistic and complementary effects of elements of safety supervision to improve the level of coal mine safety supervision and has high value of popularization and application.

Keywords: coal mine; complementary effect; safety supervision mode; synergistic effect

Sinergijski i dopunski način sugurnosnog nadzora u rudnicima: primjer rudnika ugljena u Kini

Izvorni znanstveni članak

Učinkovit sigurnosni nadzor jamči sigurnu proizvodnju rudnika ugljena. Međutim, tradicionalni način nadzora u kineskim rudnicima ugljena ne može u potpunosti ostvariti sinergijske i dopunske učinke elemenata (tj. sigurnosne inspektore) sustava sigurnosnog nadzora, što uzrokuje informaciju, primjenu i resurs kao izolirani otočić. Kako bi se prevladali ovi nedostaci i poboljšala učinkovitost sigurnosnog nadzora, u ovom je istraživanju istražena sinergijska i dodatna metoda sigurnosnog nadzora (SCSSM - Synergistic and Complementary Safety Supervision Mode). Nakon analize primjenjivosti sinergijske i dopunske ideje upravljanja, ova studija kreativno je predstavila predloženu ideju sigurnosnog nadzora u rudniku ugljena. Na osnovu nedostataka postojećeg načina sigurnosnog nadzora i prednosti sinergijskog i dopunskog upravljanja, uspostavljen je SCSSM i osigurana njegova nedvojbena metoda rada. Konačno, novi način sigurnosnog nadzora primijenjen je u Xinwen Mining Groupu Xin Julong Co., Ltd. s određenom metodom primjene 1 usporednom analizom. Rezultati pokazuju da novi način sigurnosnog nadzora koristi manje resursa sigurnosnog nadzora nego tradicionalni. U međuvremenu, poboljšani su učinkovitost provjere i ispravljanja skrivenih opasnosti te ograničeni kapacitet projekta. Štoviše, broj nesreća je smanjen, što ima značajnu sigurnosnu, ekonomsku i društvenu korist. Ova studija može ostvariti sinergijske i dopunske učinke elemenata sigurnosnog nadzora radi poboljšanja razine nadzora nad sigurnošću rudnika ugljena te ima veliku vrijednost popularizacije i primjene.

Ključne riječi: dopunski učinak; način sigurnosnog nadzora; rudnik ugljena; sinergijski učinak

\section{Introduction}

Safety management is the foundation of coal mine safety production and its effectiveness is determined by specific management measures and regulations, as well as the safety supervision methods and mechanism that ensure the effective implementation of the first two [1]. Therefore, coal mining companies must establish an efficient internal safety supervision mode that is suitable to its own development by adopting scientific safety supervision method and systematic regulation mechanism to ensure the safety and health of coal miners [2]. This finding is of vital importance in avoiding the occurrence of accidents and ensuring safety production. As high-risk workplaces, coal mines have complex and diverse working environments $[3,4]$, and unsafe operation processes cause most coal mine accidents. Thus, coal miners must comply with relevant operating rules and safety regulations in the operation process. Moreover, the safety supervision of underground working face is particularly important.

Currently, Chinese coal mining companies adopt a safety supervision mode where one safety inspector supervises one working face. This safety inspector takes charge of hidden danger management and project quality supervision of the working face. This traditional mode is good in consistently keeping a safety workplace; however, it cannot fully realize the synergistic effect of elements (i.e., safety inspectors) of the safety supervision system and it wastes safety supervision resources. All these shortcomings cause information-isolated island, application-isolated island, and resource-isolated island in the safety supervision system, as well as laziness of safety inspectors. These problems become more prominent with the improvement of mechanization and safety management levels of coal mines in China. To address these issues, scholars have applied numerous theories, including game theory, rent-seeking theory, and principalagent theory, to improve the safety supervision level in coal mines by improving the safety supervision institution, optimizing the supervision system, and

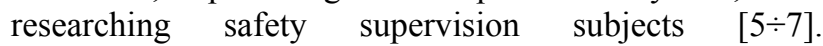
Subsequently, certain safety supervision modes have been proposed, such as the mixed and autonomous supervision mode and polycentric governance mode of coal mine safety $[8,9]$. However, supervision work in coal mines is still conducted by individual operation, and the interaction of supervision system elements is not fully realized. Moreover, mining operations have more common characteristics and are gradually transforming from individual projects to daily operations, along with the improvement of mining mechanization level. In view of the development trend of coal mine safety supervision mode, safety supervision mode is transforming from the 
division of labour into division-cooperation, and individual operation is transforming into group operation. Thus, the existing safety supervision mode cannot meet the demands of the development of coal mine safety, thereby necessitating a safety supervision mode that can fully realize the synergistic and complementary effects of the elements of safety supervision system from the perspective of team collaboration.

Based on the above mentioned conditions and given the advantages of synergistic and complementary management, this study aims to overcome the deficiencies of the existing supervision mode and improve the safety supervision level of coal mining companies by establishing a new type of synergistic and complementary safety supervision mode (SCSSM).

\section{State of the art}

As the guarantee of the safety production of coal mining company, safety supervision has been researched and practiced by many scholars, and most of these studies have focused on the safety supervision system [10-11]. Studies abroad have mainly focused on the safety and health supervision problems in coal mines. Andrew studied the formation, evolution, and social impact of occupational safety and health administration in America and utilized the existing regulation theories in the empirical study to suggest an alternative theory that more accurately reflects the findings [12]. Mills researched the emergence and growth of state responsibility for a safer and healthier British mining industry, as well as the response of labour and industry to the expanded regulation and control [13]. The practice of worker representatives to the health and safety in the Queensland coal mining industry was explored, and the vital function of worker representatives was illustrated [14]. Studies in China have also achieved success. Game theory was applied in the analysis of the interest conflict and behavior decision model in the safety supervision system in China, as well as the stability control scenarios in the coal mine safety inspection system $[15,16]$. The problems and impacts of safety supervision system were analyzed in certain studies, which adopted the principle of preventing conflicts of interest [17], principal-agent theory [6], and rent-seeking theory [5, 18]. These studies have focused on microcosmic problems, such as supervision subjects, stakeholder, and interrelationships of subjects, which are helpful to the continuous improvement of safety supervision system and safety decision accuracy. However, these studies have failed to combine practical situation and demands of safety production underground effectively and neglected the operational problems of safety supervision implementation and the deficiencies of operation procedure. Moreover, their findings have emphasized on theoretical guiding significance, and the problems of safety supervision implementation process in hazardous areas have not been solved effectively.

In the aspect of safety supervision mode, Ruffennach reviewed the development process of coal mine safety supervision mode and indicated the existing problems and improvement direction [19]. Alders and Wilthagen confirmed the importance of government regulation and enterprise supervision and suggested the adoption of a type of mixed and autonomous supervision mode [8]. Furthermore, the public management theory was applied in some studies on safety supervision of coal mine in China. For example, Li proposed the establishment of a polycentric governance mode of coal mine safety [9]. Yan and Liu established a game model of coal mine safety supervision, which was interfered by an insurance company [7]. However, these studies have neglected the feasibility and practicability of the supervision method and its operation model in coal mines, and the existing problems of safety supervision resource waste in China have yet to be solved effectively. Moreover, these studies have not fully considered the development demands of coal mine safety supervision mode and have neglected to investigate the interaction of the elements of safety supervision system. Supervision work in coal mines is mainly conducted by individual operation, and the synergistic and complementary effects of the elements of the coal mine safety supervision system are not yet fully realized. Thus, the safety supervision system in coal mines is not optimized, and the efficient operation of the safety system and the effectiveness of safety supervision function cannot be achieved.

Therefore, based on the synergistic theory and the complementary value-adding principle, this study proposes the synergistic and complementary safety supervision principle by analyzing the advantages of synergistic and complementary management, thereby addressing the insufficiencies of the existing studies. Subsequently, a new type of SCSSM is established to fully realize the synergistic and complementary effects of the elements of safety supervision system, and its operation model is provided from the perspective of safety inspector and working face. Finally, the validity of the proposed mode is tested, and the contrastive analysis of the application results can highlight the advantages of the mode and provide the basis of popularization and application.

The remainder of this study is organized as follows. In Section 3, the proposed SCSSM is established with its operation model, and an application method is designed to test the validity of this new mode. In Section 4, the application results are comparatively analyzed and discussed. Finally, the conclusions and limitations are presented in Section 5.

\section{Synergistic and complementary safety supervision mode (SCSSM)}

Based on the synergistic theory and the complementary value-adding principle, a new type of SCSSM is established in this section.

\subsection{Synergistic and complementary safety supervision principle}

Efficient system operation depends on the function and coordination degree of system elements, whereas the friction, conflict, and dissociation of system elements can increase the internal consumption of the management system and reduce system performance [20, 21]. To 
implement the overall functional effect of the system effectively, the synergistic and complementary management adopts the basic idea and method of the synergistic theory and the complementary value-adding principle to research the synergy and complementation law of management objects and its management implementation [22, 23], and highlights the ideas of synergy and cooperation among elements, and the necessary condition to achieve synergy and complementation is that partners should have a common goal and share in decision making, understanding, and knowledge; moreover, the synergistic and complementary effects of each element can be realized in terms of knowledge, experience, and ability; finally, different elements obtain synergy and complementarity on the overall system function $[21 \div 23]$. From its theoretical foundation and management idea, the synergistic and complementary management attempts to utilize the synergies and complementarities among the elements in various management systems to improve the overall system efficacy; thus, it is applicable to the research of safety supervision system. Therefore, based on the deficiencies of the existing safety supervision mode and advantages of the synergistic and complementary management, the synergistic and complementary management idea can be introduced to the safety supervision in the coal mine to fully mobilize the resources of safety supervision system and promote the synergistic and complementary effects of safety inspectors. This approach is reliable in solving the problems of the existing safety supervision mode and promoting coal mine safety production.

Under the guidance of the synergistic and complementary management idea, the recombination of time, space, and function structure of each element (safety inspector) in the safety supervision system can be realized by establishing a new type of SCSSM, and an effect of "competition-cooperation-complementation-coordination" can be generated. Through the reasonable utilization of the advantages of each element (safety inspector), the problems of information-isolated island, applicationisolated island, and resource-isolated island can be solved, and the synergistic effect and complementary effect of safety inspectors can be obtained. The essence of SCSSM is the realization of the promotion, integration, and innovation of all safety inspectors through the communication and sharing of safety information. The purpose of SCSSM is to make the overall safety supervision level of the organization much greater than the sum of each individual safety inspector on the basis of the synergistic and complementary of resources and abilities and to improve the safety production level.

\subsection{Establishment of SCSSM}

The proposed SCSSM is based on the synergistic and complementary safety supervision idea and the existing safety supervision mode. It is an efficient, scientific, and perfect safety supervision mode and method system. By circularly supervising around the working faces in the work area by the safety inspectors, the proposed mode can implement networking management, where $N$ safety inspectors manage $M$ working faces. $N$ and $M$ are assigned on one work area; $N<M$, where $M$ is the number of inspectors in the work area, and $N$ is the number of working faces in the work area. SCSSM can achieve one working face that is supervised by multiple safety inspectors, and one safety inspector inspects many working faces. The entire mode is divided into two parts, namely, supervision and management, which are interactive with each other. The management and control of hidden dangers and unsafe behaviors are conducted based on the circulatory supervision. The SCSSM flowchart is shown in Fig. 1.

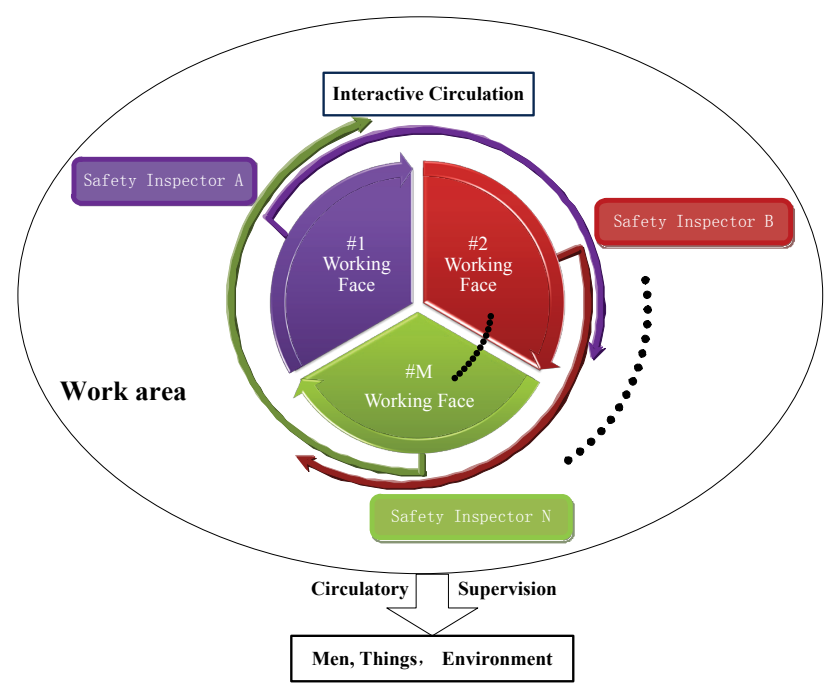

Figure 1 SCSSM flowchart

SCSSM reasonably arranges and combines the partial powers of safety supervision system. Through the recombination of each system element, SCSSM makes the new time, space, and functional structure, all of which can fully arouse the work enthusiasm of safety inspectors and improve work efficiency. Then, the free time of the safety inspector is decreased, whereas the operational use time is increased. This rational utilization of the advantages of each element (i.e., safety inspector) in the safety supervision system can promote the cognitive degree of safety inspectors to safety problems, and the utilization ratio of safety supervision resources is improved, thereby synergizing information, operation, and resources. All these findings are useful in realizing the integration and innovation of safety supervision level and obtaining the maximum benefit of safety supervision system.

\subsection{Operation model of SCSSM}

This section discusses the operation model of the SCSSM.

\subsubsection{Supervision operation model of each working face}

Each working face is simultaneously supervised by multiple safety inspectors who circularly supervise around the working faces in the work area of the coal mine. This process is supported by appropriate ensuring system and communication and coordination mechanisms. Safety inspectors supervise and inspect each working face one by one, and their knowledge, experience, ability, specialty, and thinking mode are interactive and synergistic on each 
working face. This cognitive sharing can deepen the cognition degree within the organization and enhance individual cognitive ability. Moreover, the synergy and complementation of cognitive abilities of different safety inspectors on each working face can be realized. The supervision operation model of each working face is shown in Fig. 2.

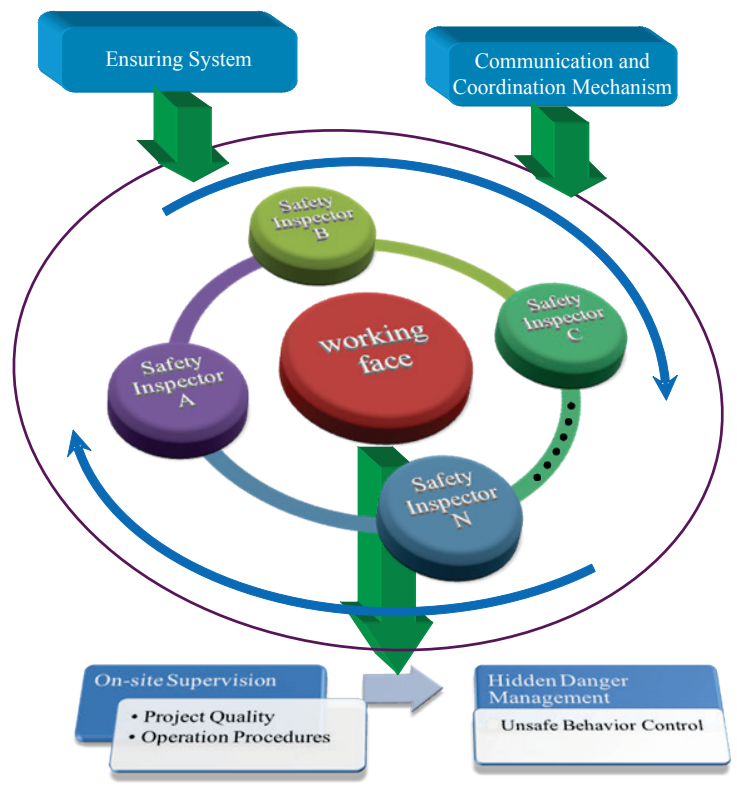

Figure 2 Supervision operation model of each working face

\subsubsection{Supervision operation model of each safety inspector}

One safety inspector manages many working faces through monitoring around the working faces in the work area and supervises the working faces one by one sequentially. In this safety supervision mode, safety inspectors can gain more experience and expand their horizon. Moreover, the habitual domains of safety inspectors are widened, and their cognitive experience in safety problems is also enriched. Through cognitive abilities such as memory, analogy, and thinking, safety inspectors can complete the accumulation of supervision and management experience in each working face, and their cognitive perspectives are widened. All these capabilities contribute in eliminating the blind spots of safety problems and finding more unsafe problems; a safe production environment can also be created. The operation model of the interactive and circulatory supervision of each safety inspector is shown in Fig. 3. This supervision and management process is also supported by appropriate ensuring system and communication and coordination mechanisms.

\subsection{Application design of SCSSM}

To characterize the validity of the SCSSM objectively, a one-year application was conducted in Xinwen Mining Group Xin Julong Co., Ltd., which is a large-scale and new mine that has the productivity of 6 million tons per year and is the largest mine in Shandong Province. This company focuses on the advanced configuration idea of large-scale, heavy-duty, and intelligent main and auxiliary systems in the coal mine and actively promotes high-end equipment assembly, advanced technology integration, and high-level talent management. Moreover, it has built highly specialized safety supervision team and developed a high-level safety management system. The safety management level and personnel quality in this coal mining company are high. However, the problem of insufficient safety resource exists, and the number of safety inspectors is insufficient to conduct the mode where one safety inspector supervises one working face. Thus, this coal mine provides suitable internal and external environments for the implementation of this mode, which is appropriate to be applied in this new safety supervision method.

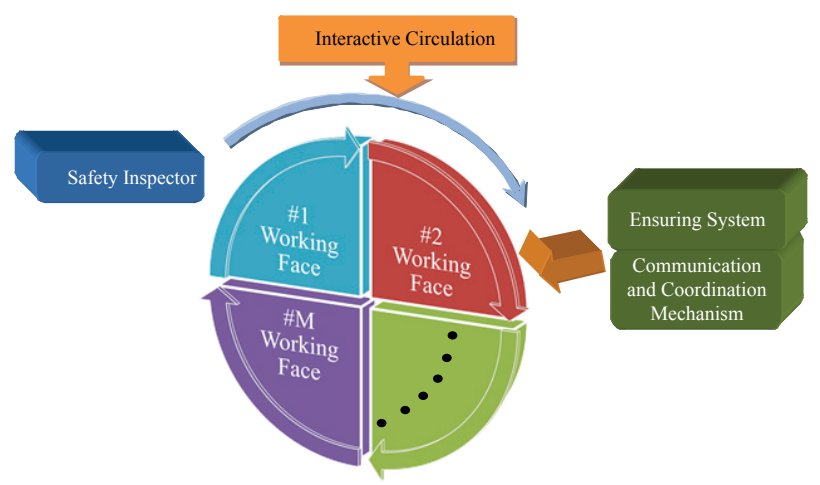

Figure 3 Operation model of interactive and circulatory supervision of each safety inspector

The implementation was conducted according to the layout of working faces and actual situation of safety supervision in the coal mine. One typical work area with three working faces was selected to implement the SCSSM in 2016. These working faces were -950 deepening jitty between sump and pump chamber (\#1 working face), $-950 \# 1$ assistant entry (\#2 working face), -950 \#1 assistant entry (\#3 working face). The interactive and circulatory supervision process of each work team in this work area is shown in Fig. 4.

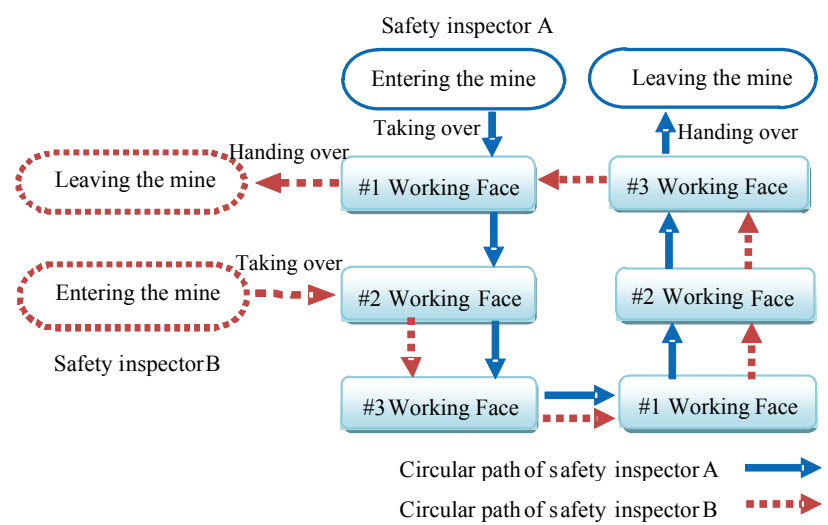

Figure 4 Interactive and circulatory supervision process of each work team - two safety inspectors and three working faces

The work area was equipped with seven safety inspectors, including one team leader and six team members. Each work team had two safety inspectors, who inspected and managed the working faces simultaneously by interactively circularly supervising their work area. As shown in Fig. 4, the specific circular path of the two safety inspectors in each work team is as follows: 
Safety inspector A: Entering the mine $\rightarrow$ Taking over $\rightarrow \# 1$ Working face $\rightarrow \# 2$ Working face $\rightarrow \# 3$ Working face $\rightarrow$ \#1 Working face $\rightarrow$ \#2 Working face $\rightarrow \# 3$ Working face $\rightarrow$ Handing over $\rightarrow$ Leaving the mine;

Safety inspector B: Entering the mine $\rightarrow$ Taking over $\rightarrow \# 2$ Working face $\rightarrow \# 3$ Working face $\rightarrow \# 1$ Working face $\rightarrow$ \#2 Working face $\rightarrow$ \#3 Working face $\rightarrow \# 1$ Working face $\rightarrow$ Handing over $\rightarrow$ Leaving the mine.

\section{Result analysis and discussion}

\subsection{Comparative analysis of the application results}

According to the application results of the implementation method, the supervision operation process of the traditional supervision mode and SCSSM is drawn. Figures 5 and 6 show the flowchart of the supervision operation process of the traditional supervision mode and
SCSSM, respectively. As shown in the figures, the vertical lines in the flowchart represent the working procedures of safety inspector, whereas the horizontal lines represent the time of every working procedure. The working face column is the name of each work face, and the sequence of every working procedure is in the sequence number column. Moreover, the working procedure column is the name of each working procedure, working hours are in the working time column, and the number of time numbers is the number of working procedure that occurred in this working face. In the flowcharts, the single blue lines represent the circulatory supervision of safety inspector A, the double amaranth lines represent the circulatory supervision of safety inspector $\mathrm{B}$, and the three red lines represent the circulatory supervision of safety inspector C.

Inspector $\mathrm{A} \rightleftharpoons$ Inspector $\mathrm{B}=$ Inspector $\mathrm{C} \equiv$

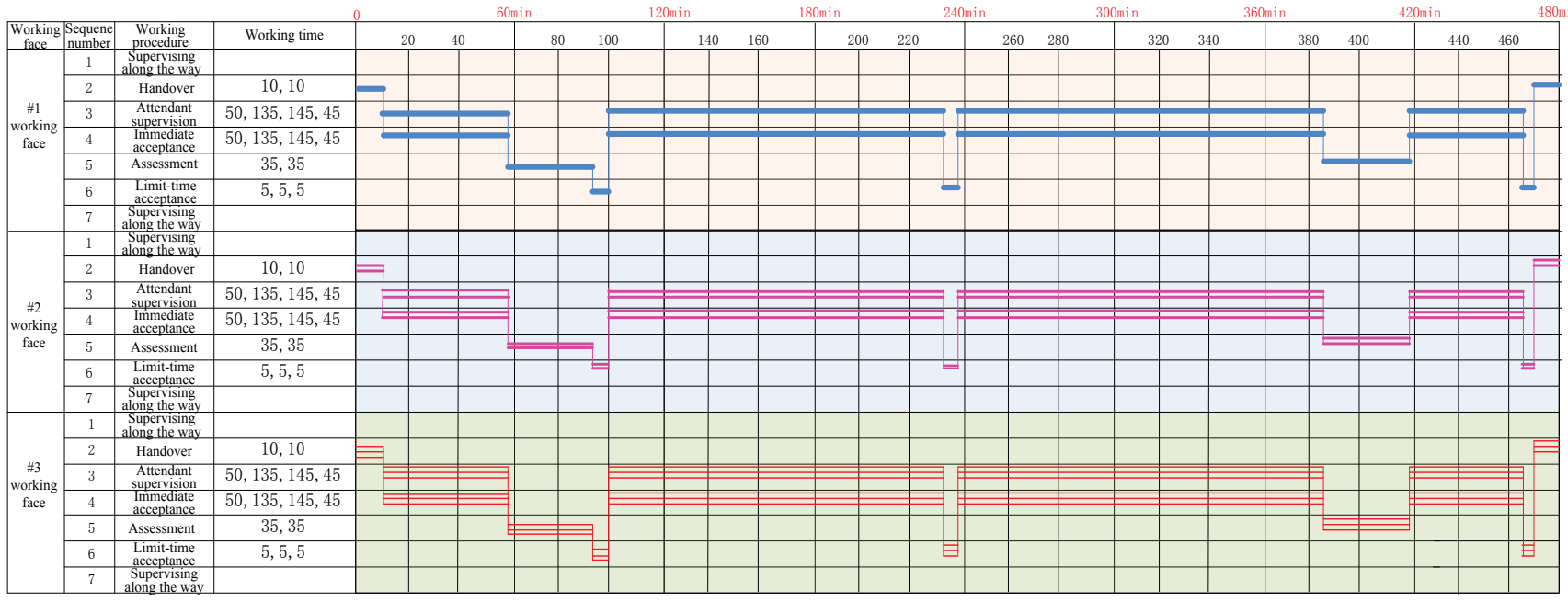

Figure 5 Supervision operation process of the traditional supervision mode

Inspector $\mathrm{A} \longrightarrow$ Inspector $\mathrm{B}=$

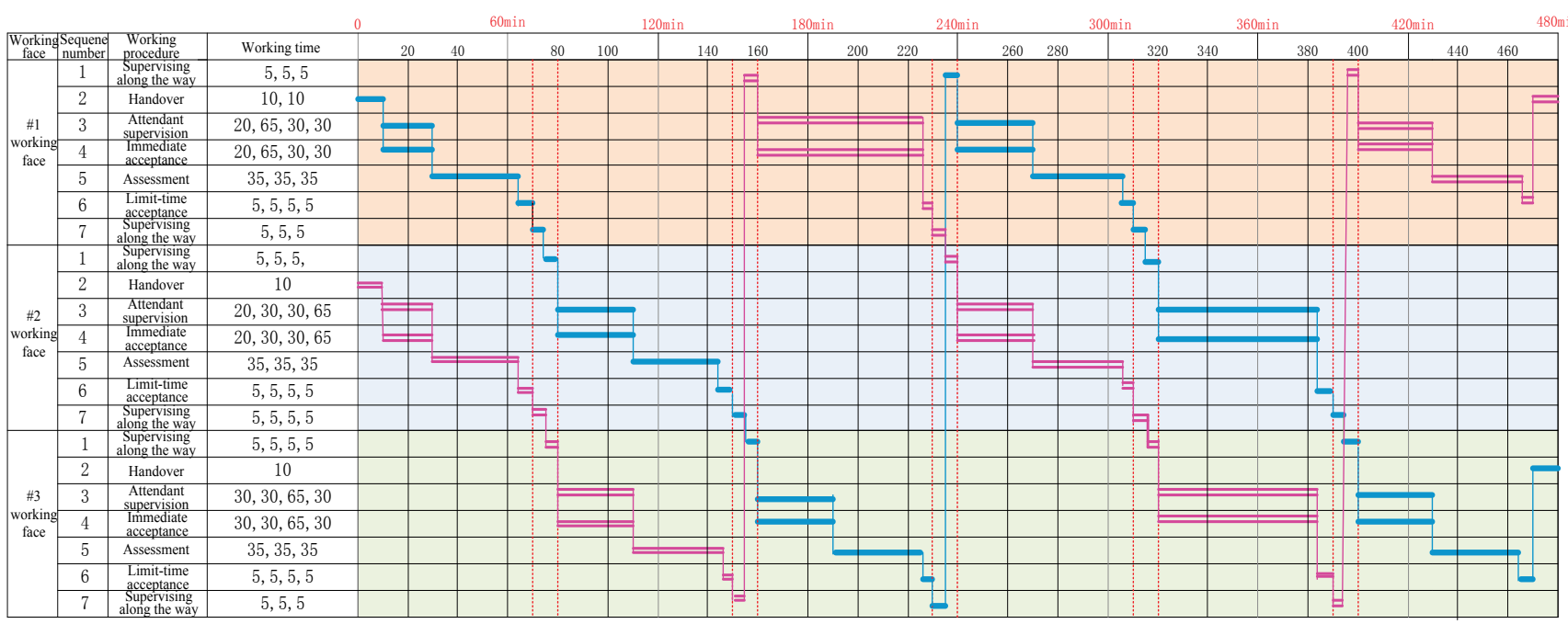

Figure 6 Interactive and circulatory supervision operation process - two safety inspectors and three working faces

Based on the operation process of the two safety supervision modes, SCSSM shows its advantages over the traditional supervision mode in many aspects, as shown in Fig. 7. Figs. 5 and 6 indicate that the SCSSM required two safety inspectors, and the traditional one required three safety inspectors. Thus, the number of safety inspectors decreased in the new mode. In the same working time, the number of evaluations per shift in each working face was two in the traditional mode, which increased to three in the new one. During the application 
of SCSSM, the range of activities of safety inspectors was extended from one working face to three working faces. In each shift, the number of supervision of each safety inspector in each working face increased from one to two. In the traditional mode, three safety inspectors worked independently, and each working face was supervised by one safety inspector, who had relatively more free time. By contrast, in the SCSSM, two safety inspectors were present, who coordinated and communicated with each other and had less free time; each working face was supervised by different safety inspectors.

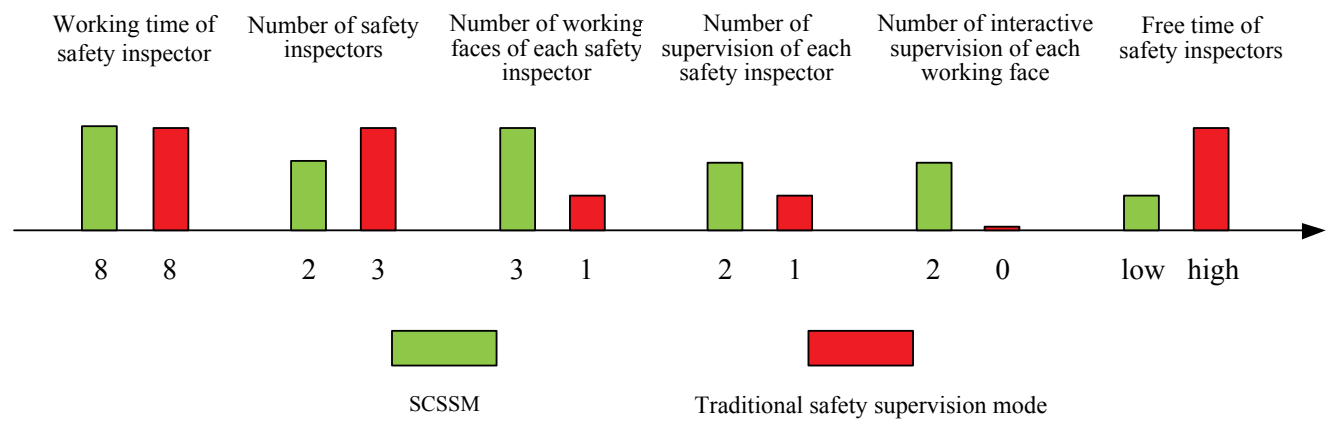

Figure 7 Comparison of the operation effect of the two modes

\subsection{Discussion}

To highlight the validity and advantages of SCSSM, the application effects of the traditional supervision mode and SCSSM were compared on the aspects of benefit, economic, and social benefits based on the data recorded in the implementation process. The data on the security effects of the two modes shown in Tab. 1 and Fig. 8 were collected during the operation of these two modes in this work area. In Table 1, the data of traditional safety supervision mode are the average value in the last two years, and those of the SCSSM are from the records and reports of the application year. The number of accidents per million hours of each quarter $(2015 \div 2016)$ is shown in Fig. 8.

Table 1 Safety factors of the two modes

\begin{tabular}{|c|c|c|}
\hline \multirow[b]{2}{*}{ Safety factors } & \multicolumn{2}{|c|}{ Safety supervision modes } \\
\hline & $\begin{array}{c}\text { Traditional } \\
\text { supervision mode }\end{array}$ & SCSSM \\
\hline $\begin{array}{l}\text { Number of safety } \\
\text { inspectors in each work } \\
\text { team }\end{array}$ & 2 & 3 \\
\hline $\begin{array}{l}\text { Number of checked } \\
\text { hidden dangers }\end{array}$ & 241 & 326 \\
\hline $\begin{array}{l}\text { Rectification rate of } \\
\text { hidden danger }\end{array}$ & $83,43 \%$ & $91,12 \%$ \\
\hline $\begin{array}{l}\text { Number of unsafe } \\
\text { behaviors }\end{array}$ & 298 & 223 \\
\hline $\begin{array}{l}\text { Qualified rate of project } \\
\text { quality }\end{array}$ & $86,31 \%$ & $94,05 \%$ \\
\hline
\end{tabular}

As shown in Fig. 7 and Tab. 1, the number of safety inspectors in the SCMM decreased in each work team, and the free time of the safety inspectors also decreased. Consequently, the labour cost was reduced, thereby solving the problem of insufficient safety resource in the company by saving safety supervision resource. For this work area, the number of safety inspectors decreased; the labour costs decreased by 20000 Yuan per month and by 240000 Yuan per year. More economic benefit can be obtained if the new mode is applied in all work areas. At the same time, SCSSM motivates the supervision initiative and enthusiasm of safety inspectors and ensures the work quality and working time. Moreover, the safety benefits are obtained from the following aspects:

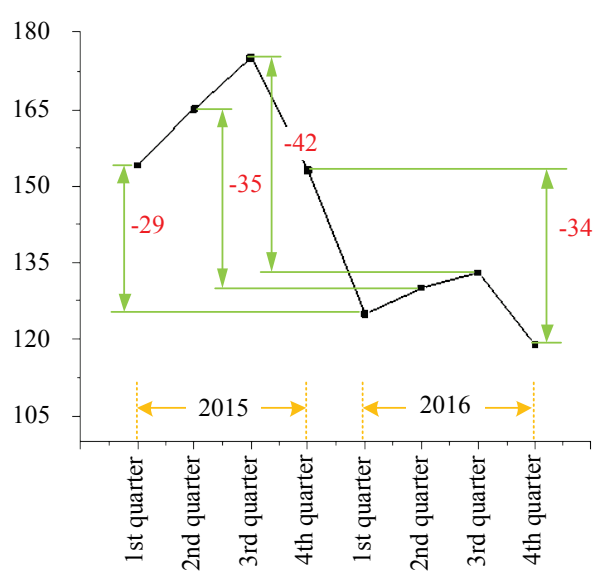

Figure 8 Number of accidents per million hours of each quarter $(2015 \div 2016)$

1) After the application of SCSSM, the number of checked hidden dangers increased from 241 to 326 per month, and the rectification rate of hidden dangers also increased by $7,69 \%$. Thus, the circulatory operation can enhance the checking of hidden dangers and make safety inspectors manage hidden dangers timely and effectively. Then, the defective condition where hidden danger rectification was not timely in this company has been eliminated.

2) As shown in Tab. 1, the number of unsafe behaviors of coal miners decreased from 298 to 223 per month in the circulatory inspection process. These data indicate that the safety level of coal miner behaviors is improved because safety inspectors circularly supervise coal miner behaviors, interactively correct the behaviors in violation of regulations, and punish coal miners for their violation. This way, the safety awareness of coal miners is strengthened, and their safety quality is improved.

3) As shown in Tab. 1, the qualified rate of project quality increased from $86,31 \%$ to $94,05 \%$. Through the exertion of synergistic and complementary effects in the supervision process, the supervision and inspection of work on-site are synergistic and complementary; thus, 
supervision contents are more elaborate and comprehensive. Then, the safety and quality management on-site is enhanced. At the same time, time availability of safety inspectors is improved, and the enhancement of work initiative and execution of safety inspectors contributes to the improvement of their professional skill.

4) The improvement of safety factors on the above three aspects directly contributes to the decrease in the number of accidents. As shown in Fig. 8, the number of accidents per million hours of each quarter was recorded from 2015 to 2016. As the production tasks in the second and third quarters of every year are relatively heavy according to the safety production plan of the mine, the two quarters have high level of coal production and tunnel advance, and the probability of accidents is relatively high. Thus, the number of accidents in the two quarters is higher than that in other quarters. As shown in Figure 8, the number of accidents recorded in the traditional supervision mode in the four quarters of 2015 is significantly higher, and the development trend of the number of accidents is relatively smooth. In SCSSM, the number of accidents in the four quarters of 2016 significantly decreased and was lower than the corresponding quarters in 2015, especially in the second and third quarters. Meanwhile, the results have the trend of a continuous decline. These results show that the effect of SCSSM is more significant in accident-prone quarters and has a sustainable and progressive increase, which is helpful to the continuous enhancement of safe production level in the coal mine.

Moreover, the SCSSM has great social benefit. This mode is a new breakthrough in the safety supervision and management methods. It also enriches the existing theory of safety production management of coal mine to set the theory and method foundation for the long-term stability of safety production. The application of this mode makes safety supervision progress toward the dynamic, circular, and synergistic team supervision mode. In addition, it promotes the wide penetration of this new mode into the coal industry and provides example and experience for other coal mining companies. Then, the new mode can make the safety supervision system more integrated, systematic, and operable to gain more social benefit.

All these favorable factors contribute to the increase in profit and improvement of efficiency, and significant safety and social benefits can be gained in the coal mining company. Therefore, SCSSM has high value of popularization and application.

\section{Conclusion}

To overcome the deficiencies of the traditional coal mine safety supervision mode and fully optimize the coal mine safety supervision system in China, the SCSSM in the coal mine was researched with its application effect tested based on the synergistic theory and the complementary value-adding principle. The main conclusions are as follows.

1) Synergistic and complementary management can realize the reasonable permutation and combination of time, space, and function structure of each element (i.e., safety inspector) in the safety supervision system. Moreover, it achieves the purpose to optimize the structure of the safety supervision system, thereby generating the "competition-cooperationcomplementation-coordination" effect.

2) The habitual domains and cognitive perspective of safety inspector are expanded through the circulatory supervision around the working faces in the work area, and the accumulation of supervision and management experience is realized. Meanwhile, the free time of safety inspectors is decreased, whereas the operational use time is increased. Consequently, the utilization ratio of safety supervision resources is improved.

3) The interactive and circulatory supervision of safety inspectors promotes the synergy of the abilities of different safety inspectors on each working face, thereby achieving the synergistic effect. Moreover, it promotes the formation of complementary advantages, ability motivation, and mutual supervision of safety inspectors, and the complementary effect in the safety supervision system can then be generated.

4) The comparison of the application of the two modes shows that SCSSM can eliminate the blind spots of safety problems, find more unsafe problems, and improve the checking and rectification efficiency of hidden dangers, as well as the project qualified rate. Furthermore, the number of accidents decreases, though lesser safety supervision resources are utilized. SCSSM provides remarkable safety, economic, and social benefits and has high value of popularization and application.

SCSSM can properly replace the traditional mode and improve the level of coal mine safety supervision. However, SCSSM was established to adapt to the improvement of coal mine safety production equipment and safety management level in China and on the condition that the coal mining company had a relatively high level of safety management and production. Thus, a coal mining company with a low level of safety management cannot effectively implement this mode. Moreover, SCSSM cannot be completely applicable in some special mining operations, such as the mining of island coal face and informal mining of boundary coal, because these operations have the characteristics of particularity and uniqueness. Thus, daily operation management is not suitable to these mines, and the mode where one safety inspector supervises one working face should be adopted in these operation processes.

\section{Acknowledgement}

The study was supported by the Social Science Research Subject of Dongying (DYSK2017-29).

\section{References}

[1] Carpenter, D. P.; Moss, D. A. Preventing regulatory capture: Special interest influence and how to limit it. Cambridge University Press, New York, 2014.

[2] Chen, H.; Chen, F. Y.; Zhu, D. D.; Qi, H.; Long, R. Y. Burnout in Chinese coal mine safety supervision. // Energy Policy. 85, 5(2015), pp. 22-31. https://doi.org/10.1016/j.enpol.2015.05.007

[3] Wang, G.; Li, W. X.; Wang, P. F.; Yang, X. X.; Zhang, S. $\mathrm{T}$. Deformation and gas flow characteristics of coal-like materials under triaxial stress conditions. // International 
Journal of Rock Mechanics and Mining Sciences. 91, 1(2017), pp. 72-80.

https://doi.org/10.1016/j.jirmms.2016.11.015

[4] Wang, G.; Wu, M. M.; Wang, R.; Xu, H.; Song, X. Height of the mining-induced fractured zone above a coal face. // Engineering Geology. 216, 1(2017), pp. 140-152. https://doi.org/10.1016/j.enggeo.2016.11.024

[5] Jia, Y. X. Effect Analysis of Coal Mine Safety Supervision Based on Rent-seeking Theory. // Social Sciences in Ningxia. 1(2011), pp. 58-60.

[6] Shen, J. J. Principal-agent analysis of coal mine safety supervision. // Legal System and Society. 14(2009), pp. 244-245.

[7] Yan, C.; Liu, W. Game Analysis on Insurance Companies Intervention in Coal Mining Safety Production Supervision Based on The Principal-agent Model. // Economic Research Guide. 15(2011), pp. 76-77.

[8] Alders, M.; Wilthagen, T. Moving beyond Command-andcontrol: Reflexivity in the Regulation of Occupational Safety and Health and the Environment. // Law \& Policy. 19, 4(1997), pp. 415-443. https://doi.org/10.1111/1467-9930.t01-1-00034

[9] Wang, L. Research on China's Coal Mine Safety Supervision Mode - a Perspective Based on the Multicenter Governance Theory. M.S. Thesis of Southwestern University of Finance and Economics, Chengdu, China, 2011.

[10] Tang, D. L. Study on the Structure and Approach of Coal Mine Safety Administration. Ph.D. Thesis of China University of Mining and Technology, Xuzhou, China, 2014.

[11] Qi, H.; Zhang, M. Y.; Chen, H.; Liu, F. F. Simulation of Chinese Coal Mine Safety Supervision System Performance Based on Netlogo Platform. // Journal of Computational and Theoretical Nanoscience. 13, 8(2016), pp. 5072-5080. https://doi.org/10.1166/jctn.2016.5384

[12] Szasz, A. The Dynamics of Social Regulation: A Study of the Formation and Evolution of the Occupational Safety and Health Administration. Ph.D. Thesis of University of Wisconsin-Madison, Madison, USA, 1982.

[13] Mills, C. Regulation Health and Safety in the British Mining Industries, 1800-1914. Ashgate Publishing Company, Burlington, 2010.

[14] Walters, D.; Johnstone, R.; Quinlan, M.; Wadsworth, E. Safeguarding Workers: A Study of Health and Safety Representatives in the Queensland Coalmining Industry. // Relations industrielles/Industrial Relations. 71, 3(2016), pp. 418-441. https://doi.org/10.7202/1037659ar

[15] Li, S.; Song, X. F. Internal and external game analysis on safety supervision in coal mining companies of China. // Journal of China University of Mining \& Technology. 39, 4(2010), pp. 610-616.

[16] Liu, Q. L.; Li, X. C.; Maureen, Hassallu. Evolutionary game analysis and stability control scenarios of coal mine safety inspection system in China based on system dynamics. // Safety Science. 80, 7(2015), pp. 13-22. https://doi.org/10.1016/j.ssci.2015.07.005

[17] Chang R. Looking at the Safety Supervision System Reform of Coal Mine in China from the International Principle of Prevention of Interest Conflict. // Journal of Chongqing Institute of Technology (Social Science). 22, 12(2008), pp. 76-79.

[18] Chen, H.; Feng, Q.; Zhu, D. D.; Han, S.; Long, R. Y. Impact of rent-seeking on productivity in Chinese coal mine safety supervision: A simulation study. // Energy Policy. 93, 2(2016), pp. 315-329.

https://doi.org/10.1016/j.enpol.2016.02.054
[19] Ruffennach, C. G. Saving Lives or Wasting Resources? The Federal Mine Safety and Health Act. Cato Institute, 2002.

[20] Zeng, J.; Zhang, Y. F. Social Synergetics. Science Press, Beijing, 2000.

[21] Meynhardt, T.; Chandler, J. D.; Strathoff, P. Systemic principles of value co-creation: Synergetics of value and service ecosystems. // Journal of Business Research. 69, 8(2016), pp. 2981-2989. https://doi.org/10.1016/j.jbusres.2016.02.031

[22] Zhang, L. B. Bohr Complimentarily Principle in Epistemological. M.S. Thesis of Nanjing University of Aeronautics and Astronautics, Nanjing, China, 2012.

[23] Cohen, J. F.; Olsen, K. Knowledge management capabilities and firm performance: A test of universalistic, contingency and complementarity perspectives. // Expert Systems with Applications. 42, 3(2015), pp. 1178-1188. https://doi.org/10.1016/j.eswa.2014.09.002

\section{Authors' addresses}

\section{Lifen Fang, Ph.D.}

(Corresponding author)

School of Economics and Management, China University of Petroleum, Room 517, No. 66, Changjiang West Road, Huangdao District, Qingdao, 266580, Shandong Province, P. R. China

E-mail: zjjhflf@163.com

\section{Zaixu Zhang, Ph.D., Professor}

School of Economics and Management, China University of Petroleum, Room 524, No. 66, Changjiang West Road, Huangdao District, Qingdao, 266580, Shandong Province, P. R. China

E-mail: zzx1766@126.com

\section{Xingdong Li, Professor}

College of Mining and Safety Engineering, Shandong University of Science and Technology, Room 215, 579 Qianwangang Road, Huangdao District, Qingdao, 266590, Shandong Province, P. R. China E-mail: 1xd7356@163.com 